\title{
DO QUOCIENTE INTELECTUAL ENTRE ALUNOS
}

\author{
Tasso Ramos de Carvalio
}

Tantos são os testes empregados para medir o desenvolvimento mental das crianças que Stern chegou a dizer que todo o professor alemão um pouco inteligente e todo auxiliar de médico escolar já inventou algum teste $^{1}$. Como conseqüência dêsse grande interêsse, hoje em dia podemos saber o nível mental de uma criança, pelo emprêgo dos testes baseados em dados experimentais ${ }^{2}$. 0 primeiro a empregar os testes como método introspectivo de psicometria foi Catell ${ }^{3}$, em 1890, porém a escala mais usada atualmente nas escolas é, sem dúvida, a de Binet-Simon. Esta escala é de fácil aplicação e de eficiência satisfatória. Várias modificações têm sido propostas, a fim de adaptar a escala de Binet-Simon aos países e às épocas.

A escala de Binet-Simon tem sido combatida em certos pontos, como por exemplo pelo fato de fornecer apenas o atraso ou progresso de determinado número de anos ${ }^{4}$. Assim, o significado do atraso não é idêntico nas diversas idades. Lembra Ninhard que "o número de crianças de 12 anos, que sofrem de um atraso de ano, é mais ou menos o duplo daquele das crianças de 6 anos; portanto, a importância do atraso ou do progresso vai diminuindo à medida que aumenta a idade da criança, e um ano de atraso, aos 5 anos, equivale, visivelmente, a um atraso de 2 anos aos 10 anos".

Com o fito de reparar esta deficiência, Terman ${ }^{5}$ faz aplicação do quociente intelectual e propõe uma classificação tendo como critério a gradação psicológica, depois de obter cêrca de 1.000 resultados. O quociente intelectual (Q.I.) foi proposto por Stern ${ }^{6}$. E' o quociente de uma fração que tem por numerador o produto da idade mental por 100 , e por denominador a idade cronológica.

A classificação de Terman, hoje aceita por todos, é a seguinte: a) Q.I. superior a 140 significa inteligência genial; b) Q.I. entre 120 e 140 representa inteligência muito superior; c) Q.I. entre 110 e 120 indica inteligência superior; d) Q.I. entre 90 e 110 exprime inteligência normal ou média; e) Q.I. entre 80 a 90 manifesta torpeza, raramente qualificada como debilidade mental; f) Q.I. entre 70 e 80 denota debilidade mental fronteiriça; g) Q.I. abaixo de 70 revela debilidade mental definida.

Sabemos ainda que a debilidade mental pode ser dividida em: a) Idiotia; b) Imbecilidade; c) Debilidade mental pròpriamente dita ?. A idiotia é a forma dos indivíduos que apresentam maior déficit mental. E: representada por todos os casos de quociente intelectual abaixo de 25. O Q.I. entre 25 e 50 significa imbecilidade, e a debilidade mental pròpriamente dita está nos limites de 50 a 70 . 
A aplicação dos testes para obter o quociente intelectual exige várias precauções, as quais foram relacionadas por Aguayo ${ }^{8}$.

Durante o ano letivo de 1948, aplicamos a escala de Binet-Simon, de 1911, ligeiramente modificada e adaptada às crianças brasileiras da época atual ${ }^{2}$, e embora os testes não tenham sido aplicados em condições ótimas, chegamos a conclusões satisfatórias.

Os testes em 45 alunos de colégios de Belo Horizonte, de idades compreendidas entre 11 e 14 anos, forneceram os seguintes resultados: Para alunos (meninos e meninas) de 11 anos a 11 unos e 11 mêses: Um com o Q.I. 72; 4 com o Q.I. entre 80 e $90 ; 12$ com o Q.I. entre 90 e $110 ; 1 \mathrm{com}$ o Q.I. entre 110 e 120. Para alunos de 12 anos a 12 anos e 11 mêses: 6 com o Q.I. entre 80 e $90 ; 8$ com o Q.I. entre 90 e 110; 2 com o Q.I. entre 110 e 120. Para alunos de 13 a 14 anos: 2 com Q.I. 80; 5 com o Q.I. entre 90 e $110 ; 4$ com o Q.I. entre 110 e 120.

Do que foi exposto, tivemos a revelação de um caso de debilidade mental fronteiriça. Trata-se do aluno A. L., de 11 anos e 10 mêses, com grau aproximado da debilidade mental definida. Cientificamos o pai de A. L. das disposições mórbidas reveladas nos testes por seu filho; infelizmente ignoramos o desenrolar dos acontecimentos, pois esta família transferia sua residência para o interior do Estado, logo após o caso relatado.

Cada vez mais nos convencemos de que a verificação do quociente intelectual entre os alunos deveria fazer parte do currículo escolar. Na verdade, isto acarretaria maiores despesas para os colégios, em virtude da necessidade de pessoal especializado. Por isto talvez, não temos dúvida de que qualquer sugestão nêste sentido esboroa ao encontrar a invencível resistência comum à totalidade dos proprietários de tais colégios. Entretanto, é assunto que deveria ser estudado pelos estabelecimentos de ensino cuja finalidade precípua não é a comercial e, muito principalmente, por aquêles custeados por verhas públicas.

Os benefícios advindos com estas medidas, por certo não se fariam esperar. Ninguém ignora "que uma educação ortof rênica ou uma reeducação terapêutica oportuna podem salvar grande percentagem de predispostos e obter a correção de disposições psicopáticas que mais adiante constituiriam motivos de preocupação séria para o psiquiaira" ${ }^{9}$.

E como descobrir as disposições psicopáticas das crianças? Elas não são notadas no lar em virtude da tendência muito humana que têm os pais de dissimular, com pejo, as taras dos filhos. Na sociedade, o convívio com pessoas que poderiam desvendá-las, nunca é suficiente. Cabe, portanto, à escola a verificação destas disposiçōes, porque só ela seria capaz de tornar exeqüíveis estas medidas reveladoras, pela aplicação dos testes em caráter obrigatório. 


\section{BIBLIOGRAFIA}

1. Székely, B. - Los tests (Primera parte). Tradução castelhana, $2{ }^{n}$ edição. Editorial Kapelusz \& Cia., Buenos Aires, päg. 60.

2. Carvalho, T. R. de - Contribuição ao estudo dos testes. "O Diário" (Belo Horizonte), 31-12-1950.

3. Carrica, M. D. C. - Educación de retardados. Librería "El Ateneo" Editorial, Buenos Aires, 1948, pág. 67.

4. Ninhard, R. -- O método dos testes. Tradução brasileira. Vol. XLIV, Cia. Editora Nacional, São Paulo, 1946, pág. 83.

5. Terman, L. M. - The measurement of intelligence. Houghton Mifflin, Boston, 1916, pág. 87 .

6. Stern, W. - Die intelligensz der kinder und jugendlichen und die methode der untersuchung. J. A. Barth, Leipzig, 1928, pág. 112.

7. Alves Garcia, J. - Compêndio de Psiquiatria, 2." edição. A Casa do Livro Ltda., Rio de Janeiro, 1948, pág. 4.53.

8. Aguayo, A. M. - Pedagogia Científica. Tradução brasileira, 4.* edição. Cia. Editora Nacional, São Paulo, 1948, pág. 182.

9. Mira y I.opez, E. - Manual de Psicoterapia. Tradução brasileira, $2 .{ }^{4}$ tiragem. Editora Científica, Rio de Janeiro, 1949, pág. 292.

Rua Goitacases, 52 (apart. 404) - Belo Horizonte, Minas Gerais. 